\title{
Ulcerative keratitis in paca (Agouti paca)
}

\author{
Ceratite ulcerativa em paca (Agouti paca) \\ Fabrício Singaretti de Oliveira' ${ }^{2}$, Denise Eliza de Almeida ${ }^{2}$, Felipe Antônio Mendes Vicenti' ${ }^{2}$, \\ Márcia Rita Fernandes Machado ${ }^{3} \&$ Júlio Carlos Canola ${ }^{2}$
}

\begin{abstract}
Ulcerative keratitis is a disorder mainly caused by fights and scratches in rodents. This disorder was described in a 7-year-old female paca with ocular secretion, blepharospasm, chemosis, conjunctival hyperemia, edema and corneal neovascularization. After anesthesia using azaperone ( $1 \mathrm{mg} / \mathrm{kg}$, i.m.), ketamine $(20 \mathrm{mg} / \mathrm{kg}$, i.m.) and xylazine $(0.2 \mathrm{mg} / \mathrm{kg}$, i.m.), plus anesthetic collyrium (hydrochloride of tetracaine $0.5 \%$ and phenylephrine $10 \%$ ), conjunctival covering of $360^{\circ}$ was performed. Subconjunctival injection of gentamicine was done and the animal was kept using an Elizabethan collar in an individual pen, receiving analgesic $(0.02 \mathrm{mg} / \mathrm{kg}$ of buprenorphine, i.m.) three times a day for 2 days and pentabiotic every 48 hours during 10 days $(30,000 \mathrm{IU} / \mathrm{kg}$ of three penicillins and $12.5 \mathrm{mg} / \mathrm{kg}$ of two estreptomicines, i.m.). After 30 days, important adhesion of the conjunctival bulb to the scarred cornea was noted and phithisis bulbi observed. The surgical technique performed preserved the eye bulb although vision was lost.
\end{abstract}

Keywords: ulcerative keratitis, Agouti paca, paca.

\section{RESUMO}

A ceratite ulcerativa é uma disordem causada principalmente por brigas e traumas em roedores. Essa afecção foi descrita em uma paca fêmea de sete anos de idade com secreção ocular, blefarospasmo, quemose, hiperemia conjuntival, edema e neovascularização corneal. Após anestesia com azaperone $(1 \mathrm{mg} / \mathrm{kg}$, IM), cetamina $(20 \mathrm{mg} / \mathrm{kg}, \mathrm{IM})$ e xilazina $(0,2 \mathrm{mg} / \mathrm{kg}, \mathrm{IM})$, além de colírio anestésico (cloridrato de tetracaína $0,5 \%$ e fenilefrina $10 \%$ ), foi realizado recobrimento conjuntival de $360^{\circ}$. Injeção subconjuntival de gentamicina $(24 \mathrm{mg})$ foi aplicada e o animal mantido com colar elizabetano em baia individual, recebendo analgésico $(0,02 \mathrm{mg} / \mathrm{kg}$ de buprenorfina, IM) por 2 dias e pentabiótico a cada 48 horas por 10 dias (30.000UI $/ \mathrm{kg}$ de três penicilinas e $12,5 \mathrm{mg} / \mathrm{kg}$ de duas estreptomicinas, IM). Após 30 dias, uma importante aderência da conjuntiva bulbar junto à córnea cicatrizada e phithisis bulbi foram observadas. A técnica cirúrgica executada proporcionou a preservação do bulbo do olho, embora tenha ocorrido perda da visão.

Descritores: ceratite ulcerativa, Agouti paca, paca. 


\section{INTRODUCTION}

The cornea is the transparent prior portion of the fibrose tunic of the eyeball, protecting vital intraocular structures, light refraction and contributing to the spherical uniformity of the bulb of the eye [1,5]. In normal conditions, the corneal transparency is maintained by a furfuraceous epithelium which is not keratinized, by the pre-corneal lachrymal film, by the absence of vascularization and pigmentation, by the even disposition and by the small diameter of the fibers of collagen which compose the corneal stroma, besides the relative corneal dehydration $[6,9]$.

Corneal ulceration is an ophthalmic disorder which is very common in veterinary medicine. Corneal ulcers are classified in accordance with the depth (surface, deep, descemetocele) and the ease with which they form a scar (complicated, simple, refractory and progressive). The surface ulcers involve the epithelium and the basal membrane with minimum involvement of the stroma. The deep ulcers extend to the corneal stroma and attain the descemetoceles reach the membrane of Descemet. The ulcerative keratitis can progress rapidly, being able to threaten one's vision [5].

In rodents, keratitis can be caused by fights and scratches. In most cases, local therapy with antibiotics and the removal of the possible cause are indicated. However, local treatment in wild rodents is not feasible, owing to the aggressive behavior of these animals. Ulcerative keratitis is very common in rodents and can also be confirmed by using fluorescein. The involvement of foreign bodies in ulcers of the cornea is very common, but the ulceration can also occur owing to fights between males kept together [3].

The objective of this report is to describe a case of ulcerative keratitis in a paca (Agouti paca), the second biggest Brazilian rodent [4]. This species has been studied as a potential experimental model due its gestational time and reduced number of newborns on each delivery [7], besides size and weight of the newborns [8]. The animal reported was bred in captivity and went through surgical procedure as treatment, aiming to preserve the eye bulb and to improve the animal's visual perception.

\section{CASE REPORT}

A 7-year-old female paca, with ulcerative keratitis and belonging to the Sector of Wild Animals of FCAV/UNESP, Jaboticabal, SP, presented hyporexia, ocular secretion and blepharospasm together in the right eye. The ophthalmic examination showed chemosis, conjunctival hyperemia, edema and corneal neovascularization, ciliar injection and deep corneal ulceration identified by the fluorescein test.

Surgical procedure was opted as treatment. Tranquilization was achieved with azaperone ${ }^{1}(1 \mathrm{mg} / \mathrm{kg}$, i.m.) and after 15 minutes ketamine ${ }^{2}(20 \mathrm{mg} / \mathrm{kg}$, i.m.) and xylazine ${ }^{3}(0.2 \mathrm{mg} / \mathrm{kg}$, i.m.) were injected together. Anesthetic collyrium of hydrochloride of tetracaine $0.5 \%$ and phenylephrine $10 \%{ }^{4}$ was also used. Conjunctival covering of $360^{\circ}$ was taken using mononylon $5-0^{5}$ in separate single knots. Subconjunctival injection of gentamicine $^{6}(24 \mathrm{mg})$ was done and the animal was kept with an Elizabethan collar (Figure 1) in an individual pen, receiving analgesic $(0.02 \mathrm{mg} / \mathrm{kg}$ of buprenorphine, i.m.) three times a day for 2 days and pentabiotic ${ }^{8}$ every 48 hours during 10 consecutive days $(30,000 \mathrm{IU} / \mathrm{kg}$ of three penicillins and $12.5 \mathrm{mg} / \mathrm{kg}$ of two estreptomicines, i.m.).

Therapy with antibiotic collyrium was not used due the necessity of daily tranquilization or anesthesia for such procedure. Ocular hygienization had to be done with diluted povidin iodine (1:50), by using a pipette.

Thirty days after surgery, the animal was anesthetized to remove the eye knots, and important adhesion of the conjunctival bulb to the scarred cornea was noted. The hygienization of the cornea continued to be done daily and, after ten more days, corneal atrophy and phithisis bulbi were observed.

\section{DISCUSSION}

The technique of conjunctival covering of $360^{\circ}$ preserved the eye bulb although vision was lost. The ulcerative keratitis described was caused by fights, as occurred in other rodents [3]. The difficulty of handling the animal owing to its aggressiveness did not allow the local antibiotic therapy [2], due the injured stroma and exposure to being potentially infected by bacteria. There was no involvement of foreign bodies in the corneal ulcer, different from that noticed previously [3].

Opacity, corneal edema and neovascularization were observed [6], and the local application of fluorescein proved to be extremely useful in diagnosing ulcerative keratitis [2].

Owing to the risk of corneal perforation, executing surgery was crucial for the treatment [2]. 


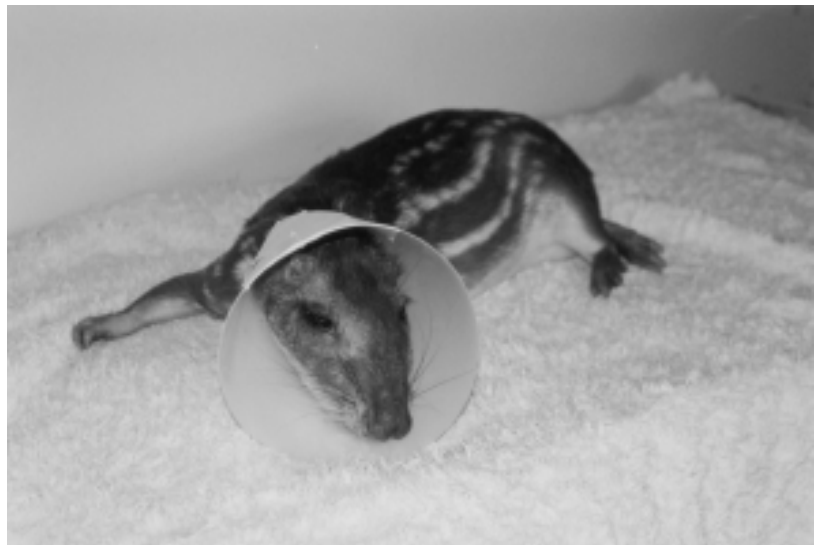

Figure 1. Adult female paca after eye surgery due ulcerative keratitis.
The conjunctival covering was performed, causing good corneal cicatrisation [5,9], as well as using therapy with systemic antibiotics and local hygienization [3].

\section{SOURCES AND MANUFACTERS}

${ }^{1}$ Suicalm ${ }^{\circledR}$, Fort Dodge Saúde Animal Ltda, Campinas, SP, Brasil

${ }^{2}$ Ketamina $50^{\circledR}$ - Holliday-Scott S.A., Buenos Aires, Argentina ${ }^{3}$ Coopazine ${ }^{\circledR}$, Coopers, São Paulo, SP, Brasil

${ }^{4}$ Colírio Anestésico ${ }^{\circledR}$, Allergan, São Paulo, SP, Brasil

${ }^{5}$ Vicryl $^{\circledR}$ - Ethicon, Johnson \& Johnson, Cincinnati, OH, USA

${ }^{6}$ Gentamicina Collírio ${ }^{\circledR}$, Allergan, São Paulo, SP, Brasil

${ }^{7}$ Temgesic $^{\circledR}$, Schering-Plough Ltda, São Paulo, SP, Brasil

${ }^{8}$ Pentabiótico Veterinário ${ }^{\circledR}$, Fort Dodge Saúde Animal Ltda, Campinas, SP, Brasil

\section{REFERENCES}

1 Collins B.K. 1996. Afecções do globo ocular: córnea e esclerótica. In: Bojrab M.J. (Ed). Técnicas Atuais em Cirurgia de Pequenos Animais. São Paulo: Roca, pp.152-161.

2 Crispin S. 2002. The cornea. In: Petersen-Jones S \& Crispin S (Eds). Manual of Small Animal Ophthalmology. London: Brithish Small Animal Veterinary Association, pp.134-154.

3 Lawton M.P.C. 2002. Exotic species. In: Petersen-Jones S \& Crispin S (Eds). Manual of Small Animal Ophthalmology. London: Brithish Small Animal Veterinary Association, pp.285-295.

4 Moojen J. 1952. Os roedores do Brasil. Rio de Janeiro: Biblioteca Científica Brasileira, 214p.

5 Moore A.P. 2003. Diagnosis and management of chronic corneal epithelial defects (indolent corneal ulcerations). Clinical Techniques in Small Animal Practice. 18(3): 165-177.

6 Morreale R.J. 2003. Corneal diagnostic procedures. Clinical Techniques in Small Animal Practice. 18(3): 145-151.

7 Oliveira F.S., Machado M.R.F. \& Canola J.C. 2003. Real time B-mode ultrasound in pacas pregnancy (Agouti paca, L.1766). Brazilian Journal of Veterinary Research and Animal Science. 40(1): 73-78.

8 Oliveira F.S., Machado M.R.F., Canola J.C. \& Camargo M.H.B. 2007. Biometry of paca newborns bred in capitivity (Agouti paca, Linnaeus, 1766). Ciência Animal Brasileira (Online). 8(4): 871-873.

9 Whitley R.D. \& Gilger B.C. 1998. Diseases of canine cornea and sclera. In: Gellat K.N. (Ed). Veterinary Ophthalmology. Philadelphia: Lippincott Williams \& Wilkins, pp.635-674. 